\title{
First report of Geochemical Characteristics of the Sangan Manganese Occurrence, Northeast Khash (Iran)
}

\author{
Mahmoudreza Kahrazehi ${ }^{1}$, Mohammad Lotfi ${ }^{1}$, Majid Ghaderi' ${ }^{2}$, \\ Mohammad Mohajjel $^{2}$ and Mohammadreza Jafari ${ }^{1}$ \\ 'Department of Geology, North Tehran Branch, Islamic Azad University, Tehran, Iran; \\ Mr_MahmoudrezaKahrazehi60@yahoo.com \\ 2Department of Geology, Tarbiat Modares University, Tehran, Iran
}

\begin{abstract}
The Sangan manganese deposit is located $28 \mathrm{~km}$ northeast of the Khash city (Southeast of Taftan volcano) in the Sistan \& Baluchistan province. Structurally and lithologically, this deposit lies in the central part of Iranian flysch zone. The ore body is layer in shape and lies above the Shale with intercalation meta sandstone - lithic tuffs of the Quaternary volcanic units contact and is completely hosted within dark gray to black lithic tuffs and in places interlinks with the dark gray to black lithic tuffs, so that the lithic tuffs play role keybed (line exploration) of manganese ore in the region. The geochemistry characteristics of the Sangan deposit was studied by means of major oxide, trace and Rare Earth Element (REE) contents and the origin of mineralization was discussed. The relatively high Al concentrations (5.95 to $7.22 \mathrm{wt} . \%$, average $=6.61$ ) in the ore of Sangan Mn deposit might result from lithic tuffs, which are the host rocks of the ore. Low titanium values ( 0.24 to $0.36 \mathrm{wt} . \%$, average $=0.31$ ) indicate limited clastic material entry during mineralization. In chondrite normalized REE graphics in all ore samples were characterized by slight negative Ce $(0.10$ to 0.11 , average $=0.11)$ and negative $\mathrm{Eu}(0.18$ to 0.22 , average $=0.20)$ anomalies. The negative Ce anomaly was typical to hydrothermal deposits and negative Eu anomaly indicates contamination from the continental crust and or sediment contribution via dehydration. The available data like; Mn:Fe (average 4.07), relatively high Ba (average 508,50), Co:Ni (average 0.18), Co:Zn (average 0.34), total REE (average 117.94), LREE > HREE, LREE:HREE (average 10.33), La:Ce (average 0.56), slight negative Ce and Eu anomalies and discrimination diagrams for $\mathrm{Mn}$ deposits indicated that the Sangan manganese deposit is hydrothermal type volcano-hydrothermal mineralization.
\end{abstract}

Keywords: Geochemistry, Hydrothermal, Iran, Khash, Manganese, Sangan

\section{Introduction}

A variety of features of manganese deposits, such as geochemistry, distribution, composition, and their formation environments are considered in many of publications ${ }^{1}$. It is now generally understood that manganese deposits have diverse origins. They can be formed by various processes, including sedimentary, hydrothermal, hydrogenous, and super gene. Hydrothermal manganese deposits are smaller than sedimentary manganese deposits ${ }^{2}$. Hydrothermal manganese deposits are directly precipitated from low temperature hydrothermal solutions $^{3}$. These deposits are generally of laminated and strata bound or occur as irregular bodies and epithermal veins. They are formed in different tectonic settings, such as the marine environment next to spreading centers, intraplate seamounts, or in subduction related island arc settings, and are found in both modern and ancient geologic environments ${ }^{4,5}$. Hydrothermal deposits are characterized by high $\mathrm{Mn}$ :Fe content and low trace metal concentrations $s^{6,7}$. Manganese and ferromanganese ore deposits are recognized with different ages and geologic settings in Iran ${ }^{8}$. For example, the Infracambrian Narigan Mn ore deposit in Yazd province (Central Iran) has a volcano-exhalative genesis. The Cretaceous Benvid Mn deposit $35 \mathrm{Km}$ south of Nain-Isfahan, with possible sedex genesis and Kamar Talar Mn deposit in Sistan suture zone, East Iran'. There has been no detailed investigation

*Author for correspondence 
on the origin of the Mn mineralization from the Sangan area. Therefore, the purpose of this paper is to discuss field observations in conjunction with major, trace, and rare earth element (REE) geochemical data to constrain the genesis of $\mathrm{Mn}$ ore deposit in the Sangan region, Southeastern Iran.

\section{Geological Setting}

The Iran plate is part of northern margin of Gondwana which is separated from Eurasia by the paleotethys Ocean. The movement of bloks along folds and tectonic force are the main factors which played prominent roles in shaping the structural characteristics and geology of Iran. The Pressures and Strains to the Iran plate caused the region to be classified based on different theories in to several tectonic units ${ }^{10-15}$. The studied area is located in the central part of Iranian flysch zone. This zone is located between Lut Block to the west and Helmand (in Afghanistan) to the east. In contrast to Lut Block, the Flysch Zone is highly deformed and tectonized and consists of thick deep-sea sediments like argillaceous and silicic shales, radiolarite, and pelagic limestone and volcanic rocks such as basalt, spilitic basalt, diabase, andesite, dacite, rhyolite, and subordinate serpentinized ultramafic rocks. The basement is likely composed of an oceanic crust. Most rock units in this zone fall into three main groups: 1- Flyschoid sediments, 2-Volcanic, volcano sedimentary and intrusive rocks 3 -Ophiolitic series ${ }^{16}$. However there are some other names of this zone such as Nehbandan-khash zone ${ }^{17}$, Zabol-Baluch zone $^{13}$, Flyschzone ${ }^{18}$ Sistan suture zone ${ }^{19}$, Iran East mountain $^{20}$. The Sangan manganese Occurrence is Located $28 \mathrm{~km}$ Northeast of Khash city (Southeast of Taftan volcano) and $1 \mathrm{~km}$ West of Sangan village (N28-31-9.3, E61-15-42.3). Based on the Geological Map (1:1000 Scale), the Most Important Rock unites around deposit consists of gray to light green shale with intercalation meta sandstone, Dark gray to black lithic tuffs, white to milky ignimbrite tuffs and recent alluvium. Manganese Mineralization is associated with dark gray to black lithic tuffs within Quaternary volcanic units (Figure 1 A, B and Figure 2).

\section{Materials and Method}

10 ore samples ( $\sim 500 \mathrm{~g}$ each) were collected systematically from the Sangan manganese deposit. All this ore samples for geochemical analyses were taken representatively from the surface outcrop of ore beds in different locations. Samples powders under 200 meshes were analyzed at Kansaran Binaloud Laboratories, Tehran, Iran. Major oxide and trace element contents were determined with XRF and ICP-OES Respectively. REE's were analyzed with ICP-MS method. Results of analysis are given in Tables 1,2 and 3.

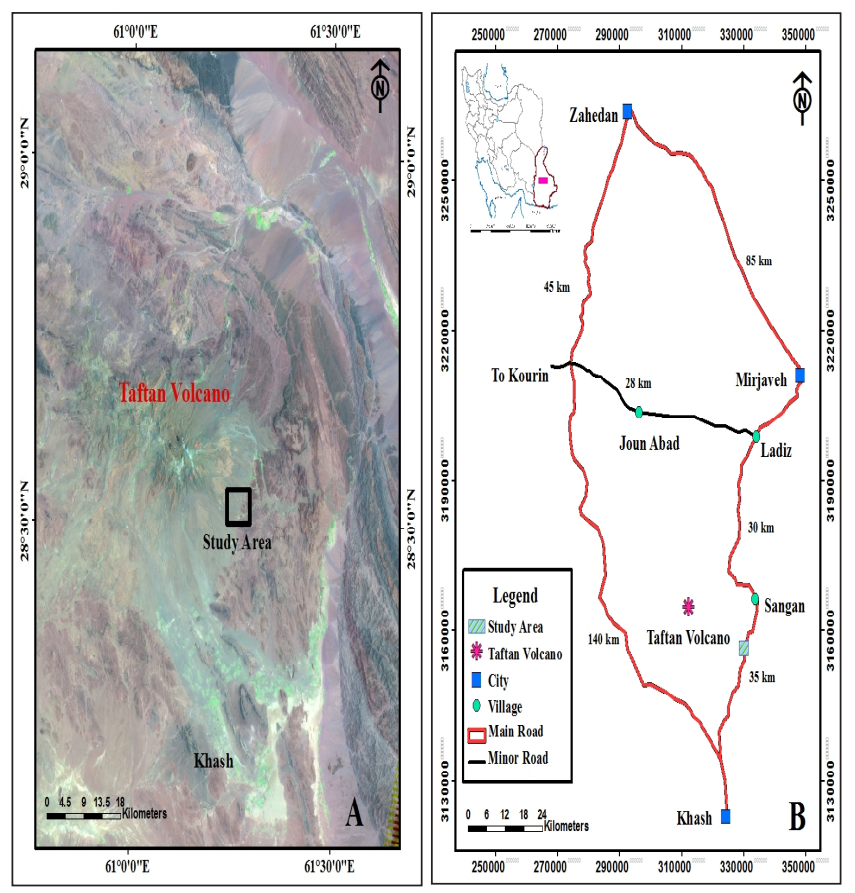

Figure 1. Satellite image (A) and Geographical position (B) of the study area in Southeastern Iran

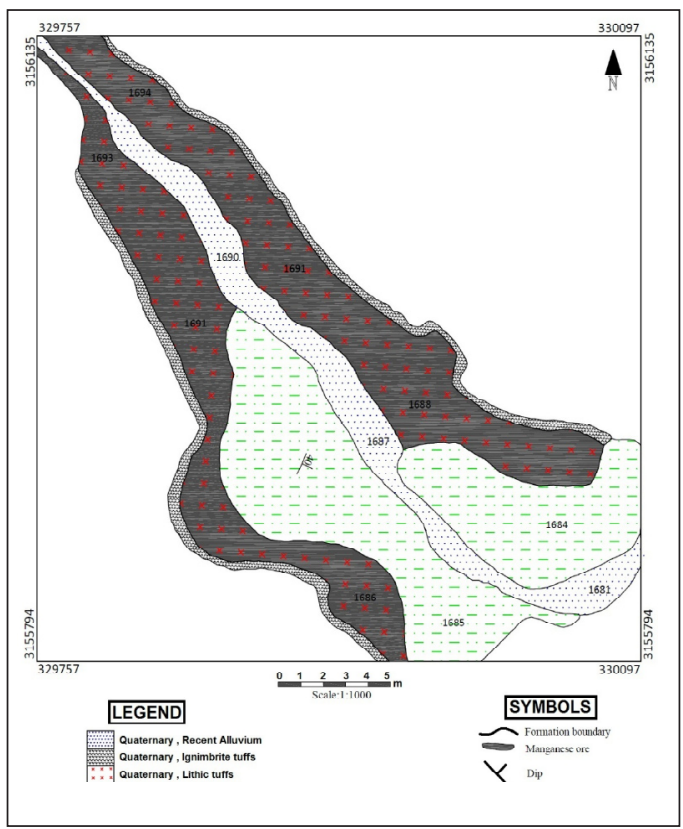

Figure 2. Geological map (1:1000 scale) of the study area in Southeastern Iran. 


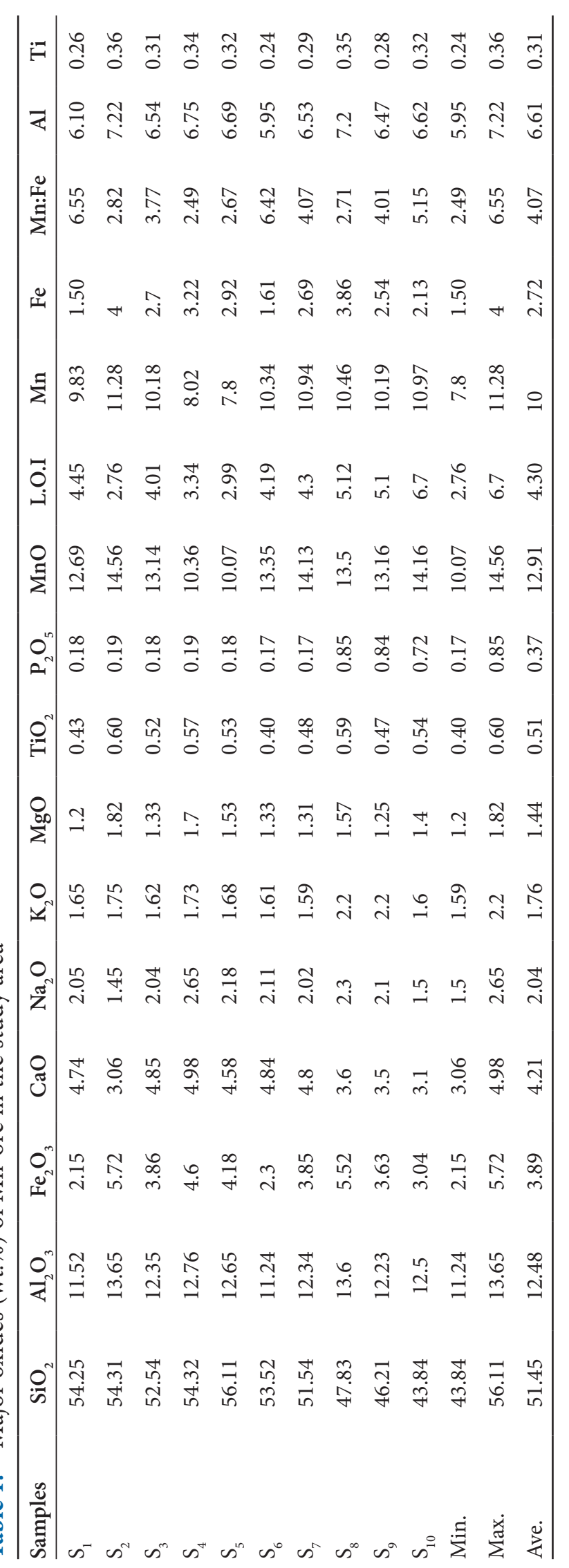

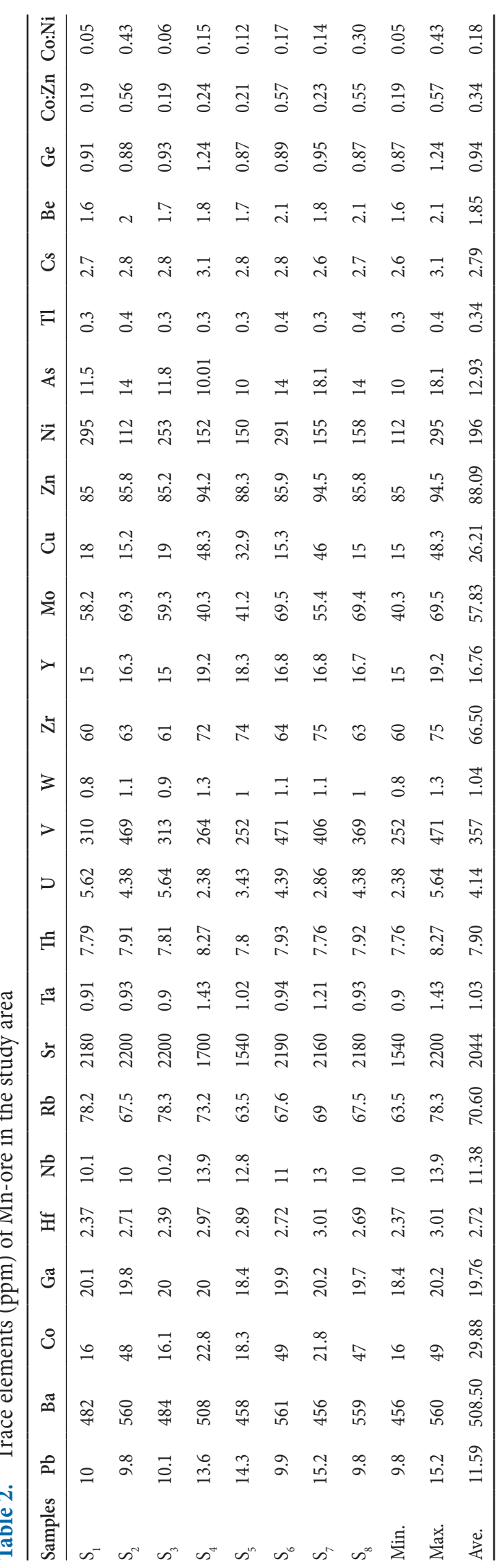

Indian Journal of Science and Technology 


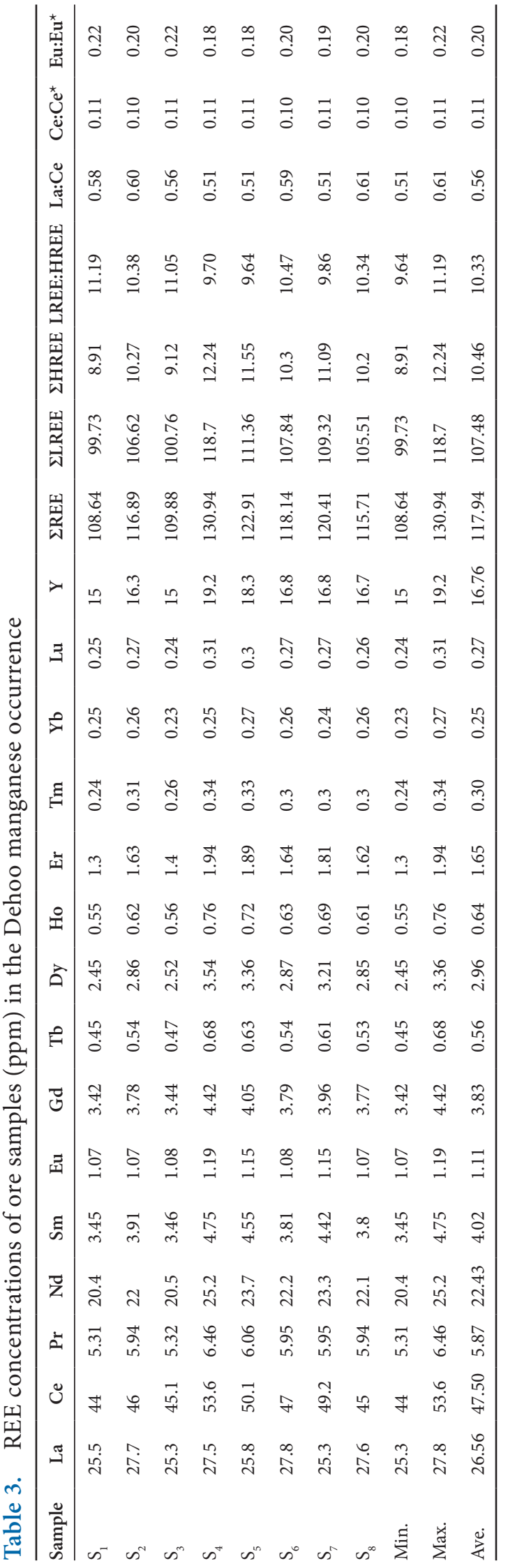

\section{Results and Discussion}

\subsection{Field Observations}

The ore body in the study area is layer in shape. The ore body lies above the Shale with intercalation meta sandstone-lithic tuffs contact and is completely hosted within dark gray to black lithic tuffs and in places interlinks with the dark gray to black lithic tuffs, so that the lithic tuffs play role keybed (line exploration) of manganese ore in the region. Wherever we have this rock unit (lithic tuffs), manganese mineralization could be observed as scattered grains in the space between ashes and pyroclastic particles. But, these pyroclastic particles have been crashed in some places and there have been some fine fractures between them that they are also filled with manganese oxide ores result from volcanic activities. The ore layers generally vary in thickness from 1 to $2 \mathrm{~m}$, in length from 400 to $800 \mathrm{~m}$ and wide from 4 to $8 \mathrm{~m}$. The ore trends approximately eastwest to northwest-southeast and dips southeast between $20^{\circ}$ and $25^{\circ}$. Ore has been exploited mainly by small-scale miners using rudimentary methods at Sangan (Figure 3).

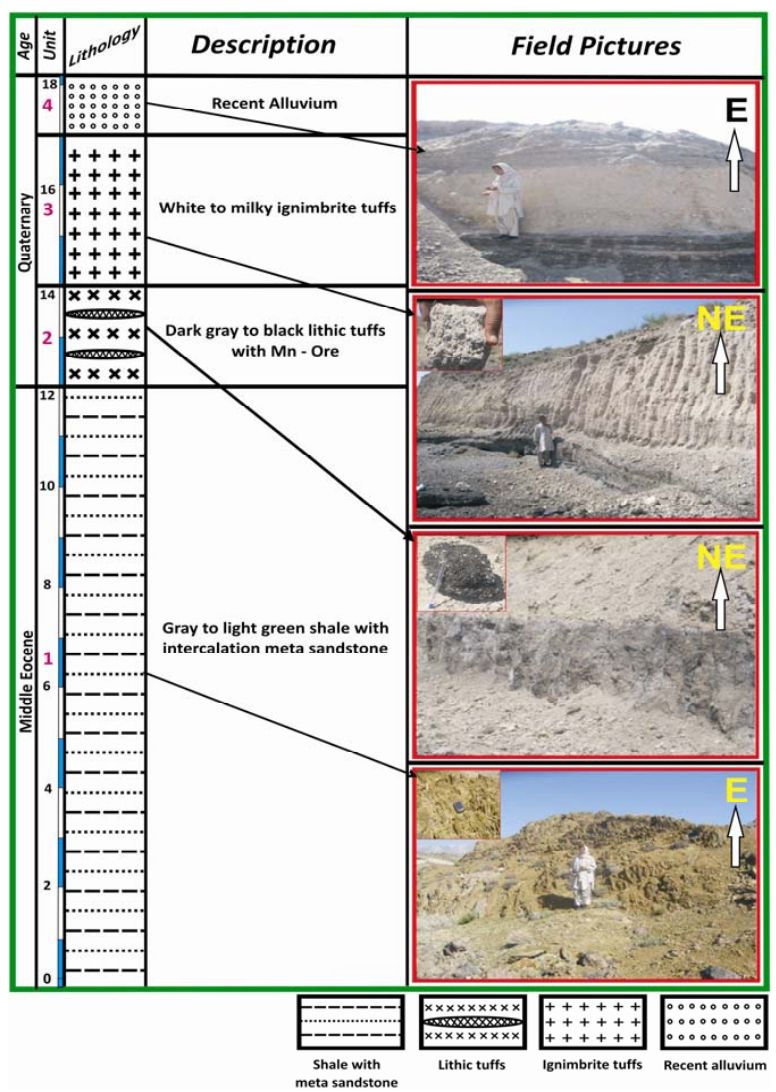

Figure 3. General lithological column of the study area in Southeastern Iran. 


\subsection{Major and Trace Elements Geochemistry}

Geochemical criteria to distinguish ferromanganese deposits of various origins are well established. Major element ratios, trace element concentrations have been widely used to assess the origin of manganese deposits ${ }^{21-23}$. Among the major oxides, $\mathrm{Mn}, \mathrm{Fe}, \mathrm{Ti}$ and $\mathrm{Al}$ contents are very useful to delineate the origin of manganese ores ${ }^{23,24}$. Many authors use Mn:Fe ratio as discrimination genetic factor between manganese deposits; for example; this ratio in lacustrine deposits is $(\mathrm{Mn}: \mathrm{Fe}<1)$, hydrogenous $(\mathrm{Mn}: \mathrm{Fe}=1)$ and Sedex deposits $(0.1<\mathrm{Mn}: \mathrm{Fe}<10)^{25}$. Analytical results of the major and trace elements of the Sangan Mn deposit are given in Tables 1 and 2. Mn concentration ranges from 7.8 to $11.28 \mathrm{wt} . \%$ (average = 10 ), and Fe ranges from 1.50 to 4 wt. $\%$ (average $=2.72$ ) in the Sangan Mn deposit. Mn:Fe ratios of the deposit are $2.49-6.55$ (average $=4.07)$ (Table 1). These values are relatively conformable with those of hydrothermal manganese deposits. Like Fe and $\mathrm{Mn}$ contents, Aluminium and Titanium concentrations are used for the identification of manganese mineralization, and $\mathrm{Al}$ is generally related to clay minerals in the sediments ${ }^{26}$. $\mathrm{Ti}$ is immobile in hydrothermal solutions and as such is measure of clastic input $^{21,27,28}$. The relatively high concentrations of $\mathrm{Al}$ values in Mn oxide deposits also suggest a significant sedimentary contribution during precipitation ${ }^{29}$. Al concentrations of ore samples in the Sangan deposit range from 5.95 to 7.22 wt.\% (average $=6.61$ ), and Ti concentrations range from 0.24 to 0.36 wt.\% (average $=0.31)($ Table 1$)$. The relatively high $\mathrm{Al}$ concentrations in the ore of Sangan $\mathrm{Mn}$ deposit might result from lithic tuffs, which are the host rocks of the ore. Low titanium values indicate limited clastic material entry during mineralization.

The hydrogenous and hydrothermal deposits can be distinguished by using $\mathrm{Co}: \mathrm{Ni}$ and $\mathrm{Co}: \mathrm{Zn}$ ratios30. A ratio of $\mathrm{Co}: \mathrm{Ni}<1$ and $\mathrm{Co}: \mathrm{Ni}>1$ indicates a sedimentary origin and a deep marine environment, respectively28,31-33. Co:Ni ratio in the Sangan Mn deposit range from 0.05 to 0.43 (average $=0.18)($ Table 2$)$. Co:Zn ratio of 0.15 indicates hydrothermal type deposits, while Co:Zn ratio of 2.5 indicates hydrogenous type deposits30. Co:Zn ratio in the Sangan Mn deposit range from 0.19 to 0.57 (average $=0.34)$ (Table 2). Although Co:Zn ratio from the Sangan Mn deposit point to a hydrothermal source for $\mathrm{Mn}$ mineralization, $\mathrm{Co}: \mathrm{Ni}$ ratio of ore samples indicate that sedimentary environments played an important role during the formation of the Mn deposit.
Ba concentrations in hydrothermal solutions are higher than seawater because of the influence of volcanic activity and sedimentation ${ }^{28,33,34}$. Ba concentrations in the Sangan manganese deposit range from 456 to $560 \mathrm{ppm}$ (average $=508.50$ ) reflecting in general, the characteristics of hydrothermal deposits.

Different major and trace element discrimination diagrams have been proposed by many workers to distinguish manganese ores of various origins ${ }^{26,29,30,35-41}$. These discrimination diagrams have been used to distinguish between a hydrothermal (continental or marine) and a hydrogenous origin. The term hydrothermal refers to manganese oxides deposited directly from geothermal waters around hot springs and pools in continental environments or sedimentary-exhalative manganese mineralization deposited in marine environments $\mathrm{s}^{38}$. The term hydrogenous refers to deposits formed by slow precipitation or adsorption of dissolved components from sea water ${ }^{26,36,38}$. The Si vs. Al binary diagram ${ }^{30,39}$, the $\mathrm{Mn}-\mathrm{Fe}-(\mathrm{Co}+\mathrm{Ni}+\mathrm{Cu}) \times 10$ triangular diagram ${ }^{26,36,41}$, the $\mathrm{Zn}-\mathrm{Ni}$-Co triangular diagram ${ }^{29}$, the $\mathrm{Co}: \mathrm{Zn}$ vs. $\mathrm{Co}+\mathrm{Ni}+$ $\mathrm{Cu}$ diagram $^{30}$, and the $\mathrm{Co}+\mathrm{Ni}$ vs. As $+\mathrm{Mo}+\mathrm{V}+\mathrm{Cu}+$ $\mathrm{Pb}+\mathrm{Zn}$ diagram ${ }^{37}$ are used in this study to discriminate between the hydrothermal and hydrogenous character of the deposit.

All the studied manganese ore samples in triangular (Figure 4B and C) and binary (Figure 4A, D and E) discrimination diagrams plot within the hydrothermal field. Trace element concentrations in the manganese oxides show the mostly hydrothermal origin for manganese deposit in the Sangan region (Table 2; Figure 4A to E).

\subsection{Rare Earth Elements Geochemistry}

Major oxide, trace and REE geochemistry are very useful for understanding the formation conditions of ore deposit. REE contents of 8 ore samples collected from the Sangan manganese deposit are listed in Table 3. Hydrothermal deposits show relatively low REE, but hydrogenous deposits have a significantly higher amount ${ }^{28,42-44}$. The total REE ( $\mathrm{REE}$ ) concentrations of Sangan $\mathrm{Mn}$ ore range from 108.64 to $130.94 \mathrm{ppm}($ average $=117.94)($ Table 3$)$, the low contents of REE composition of studied ore samples are conformable with hydrothermal manganese deposits ${ }^{23,45}$. Total light REE: heavy REE (i.e., $\Sigma$ LREE: $\Sigma$ HREE) and La:Ce ratios of the Sangan Mn ore given in Table 3, can be used as an indicator of primary enrichment during the Mn oxidation processes ${ }^{28,33,46}$. LREE $>$ HREE value may indicate mineralization related to hydrothermal 

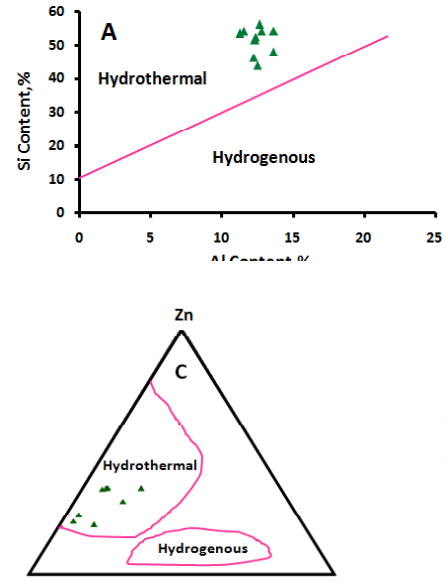
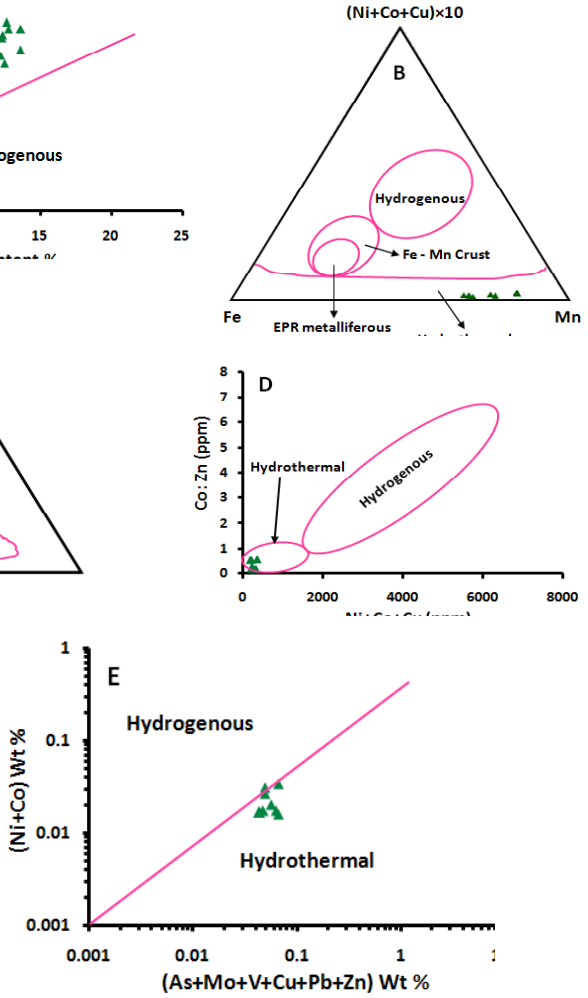

Figure 4. Discrimination diagrams for manganese deposits. (A) Si vs. Al discrimination diagram ${ }^{30,39}$, (B) Mn$\mathrm{Fe}-(\mathrm{Ni}+\mathrm{Co}+\mathrm{Cu}) \mathrm{x} 10$ discrimination $\operatorname{diagram}^{26,36,41},(\mathrm{C})$ $\mathrm{Zn}-\mathrm{Ni}-\mathrm{Co}$ discrimination diagram ${ }^{29}$, (D) $\mathrm{Co}: \mathrm{Zn}-\mathrm{Co}+\mathrm{Ni}+$ $\mathrm{Cu}$ discrimination diagram ${ }^{30}$ and (E) $\mathrm{Co}+\mathrm{Ni}$ vs. As $+\mathrm{Mo}+$ $\mathrm{V}+\mathrm{Cu}+\mathrm{Pb}+\mathrm{Zn}$ discrimination $\operatorname{diagram}^{37}$.

solutions ${ }^{28,33,47}$. The total LREE: total HREE ratio ranges from 9.64 to 11.19 (average $=10.33$ ) in the Sangan Mn ore. These values indicate that hydrothermal solutions played an important role in the formation of Sangan Mn deposit. Hydrothermal crusts have La:Ce ratios similar to seawater ( 2.8), but hydrogenous Mn-Fe crusts have a much lower La:Ce ratio $(\sim 0.25)^{48}$. La:Ce ratio for the Sangan Mn ore vary between 0.51 and 0.61 (average 0.56) (Table 3 and Figure 5). This ratio suggests a major input from a hydrothermal source for the Sangan Mn ore Figure 5.

Although the relationship between manganese deposits and their REE distribution has been studied ${ }^{49-52}$, there is no generally accepted model for reflecting the deposit type (e.g., hydrothermal, diaganetic, hydrogenetic) and oxidative and reductive deposition conditions. $\mathrm{Ce}$ and Eu, the two most important REEs, are commonly used for the prediction of fluid source and redox potential of the environment. $\mathrm{Ce}$ and $\mathrm{Eu}$ anomalies are defined as Ce:Ce $=\left[\left(\mathrm{Ce}_{\mathrm{n}}\right):\left(\mathrm{La}_{\mathrm{n}} \times \mathrm{Pr}_{\mathrm{n}}\right)^{1 / 2}\right.$ and $\mathrm{Eu}: \mathrm{Eu}^{*}=$

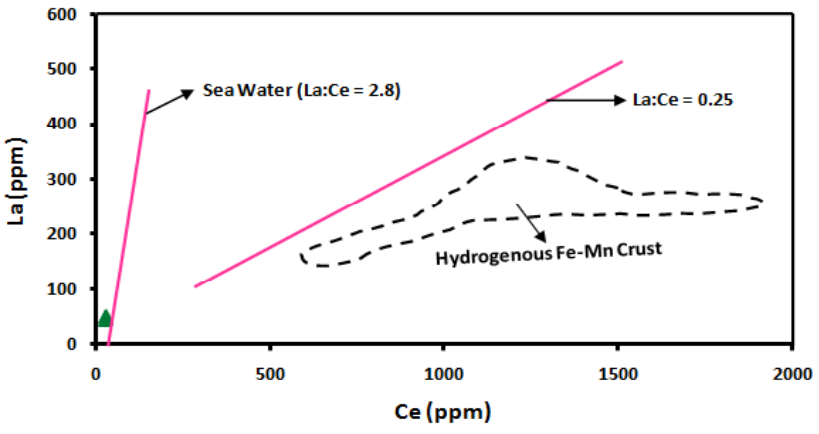

Figure 5. Plot of Sangan $\mathrm{Mn}$ ore on the $\mathrm{La}$ vs. Ce discrimination diagram ${ }^{30,48}$.

$\left[\left(\mathrm{Eu}_{\mathrm{n}}\right):\left(\mathrm{Sm}_{\mathrm{n}} \times \mathrm{Gd}_{\mathrm{n}}\right)^{1 / 2}\right.$, respectively, where $\mathrm{Ce}^{*}$ and $\mathrm{Eu}^{*}$ are the hypothetical concentrations ${ }^{53}$. The subscript " $n$ " indicates chondrite-normalized values ${ }^{54}$.

Slight negative $\mathrm{Ce}$ anomalies are considered as an indicator of volcanogenic input ${ }^{55}$ or hydrothermal contributions to seawater ${ }^{50,51}$, whereas a strong negative $\mathrm{Ce}$ anomaly is characteristic of low temperature hydrothermal deposits around the hot spots in mid-ocean and island arc spreading centers ${ }^{56,57}$.

Positive Ce anomalies are characteristic for modern seafloor oxyhydroxide deposits and nodules ${ }^{58}$. A negative Ce anomaly is observed in all ore samples taken from the Sangan Mn ore (Table 3). Ce:Ce $\mathrm{C}^{\star}$ anomaly values range between 0.10 and 0.11 (average $=0.11$ ) a range which is similar to low temperature hydrothermal deposits.

A positive Eu anomaly in hydrothermal deposits suggests high temperature hydrothermal fluids ${ }^{59}$ and reflects the interaction of heated waters with substrate volcanic rocks of high Eu content during circulation ${ }^{60}$. A negative Eu anomaly indicates an insufficient interaction of ground water with substrate volcanic rocks due to low temperature $^{60}$ and contamination from the continental crust and or sediment contribution via dehydration ${ }^{28,33,61}$.

A negative Eu anomaly is found in all the manganese samples taken from the Sangan Mn ore (Table 3). Eu:Eu* anomaly values range from 0.18 to 0.22 (average $=0.20$ ). This suggests a low temperature hydrothermal solution, which affected mineralization. We conclude that REE patterns of the Sangan manganese deposit are generally similar to those from hydrothermal manganese deposits. All the studied ore samples shows light negative Ce and negative Eu anomalies (Figure 6).

REE patterns of the region (Figure 6) are compared with those of hydrothermal and hydrogenous manganese deposits (Figure 7). Results indicate that hydrogenous 


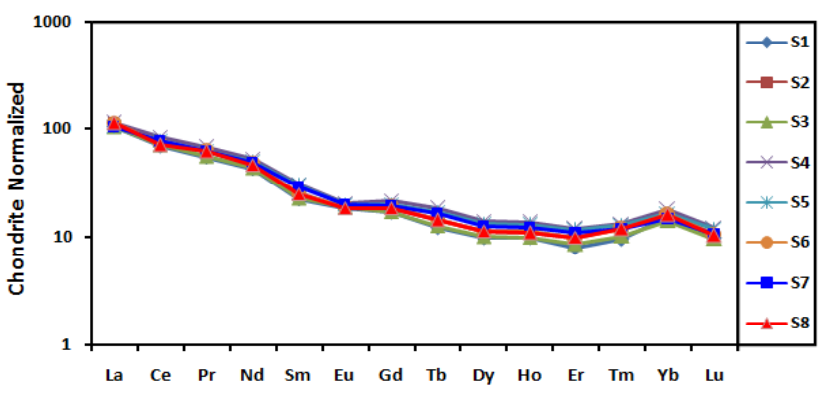

Figure 6. Chondrite-normalized REE patterns of the Sangan ore samples, chondrite values are from ${ }^{54}$.

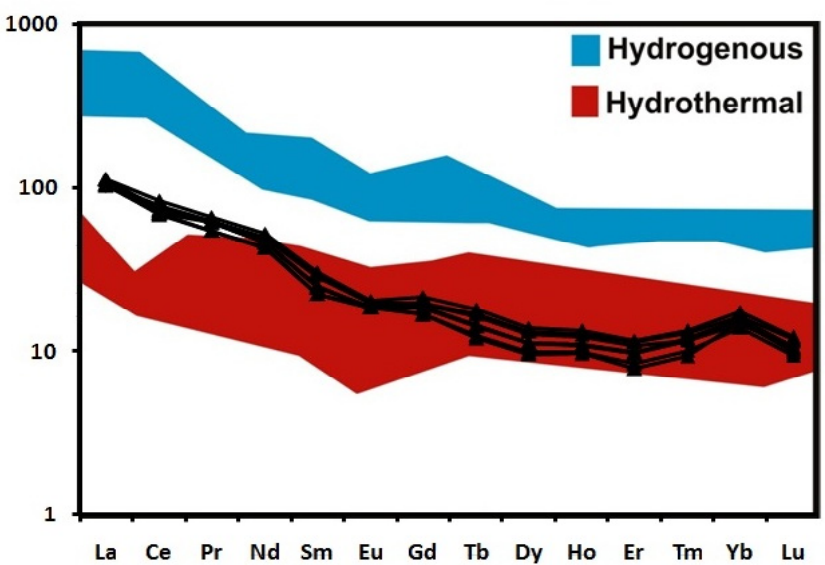

Figure 7. Chondrite-normalized REE patterns of the Sangan ore samples compared with different type of hydrogenous $^{63}$ and hydrothermal ${ }^{60}$ manganese deposits. Chondrite values are from ${ }^{54}$.

manganese deposits are more enriched in REE's than their hydrothermal equivalents and hydrogenous manganese deposits are represented by positive Ce anomaly, but hydrothermal deposits are characterized by negative Ce anomalies ${ }^{3,62}$. Ore samples of the Sangan manganese deposit show slight negative $\mathrm{Ce}$ anomalies which resemble the pattern of hydrothermal deposits (Figure 6). Eu shows negative anomaly in all ore samples indicating contamination from the continental crust and or sediment contribution via dehydration ${ }^{33,61}$.

\section{Conclusions}

The Sangan manganese deposit is associated with Dark gray to black lithic tuffs within Quaternary volcanic units at $28 \mathrm{~km}$ Northeast of Khash city (Southeast of Taftan volcano) and $1 \mathrm{~km}$ West of Sangan village (N28-31-9.3, E61-15-42.3). Major oxide, trace and REE element assessment show that hydrothermal activities were effective for the formation of the Sangan manganese deposit. Also, the studies reveal that mineralization of manganese in layered form and strati form and related to Dark gray to black lithic tuffs with quaternary age, which is generally conformable with bedding host rock (lithic tuffs). The contacts with the tuffs are suddenly and associated with pyroclastic-volcanic activities of Taftan volcano. They have been formed as the horizontal layers and placed on the middle Eocene folded flysches unconformably. Therefore, it can be concluded that both volcanic and hydrothermal conditions were caused in the formation of Sangan manganese deposit which may be described as related to volcano-hydrothermal occurrence. It seems that hydrothermal fluids and volatile materials with high hydraulic pressure and explosively are ejected and exited from a further volcanic source related to Taftan Volcanism and have passed distance due to the low density and gradually have been deposited as horizontally and unconformably on the middle Eocene flysches. The question is why they have been found in only one horizon and contaminated with manganese oxides. Manganese along with other materials such as volcanic ashes and pyroclastic fragments during the exit of the volcanic channel do not react with oxygen at the same time, because Manganese has low ionic potential, it takes a short time, which coincided with an explosion of volcanic ashes and pyroclastic fragments and finally it's deposition. In the case of fine-grained material impregnated with manganese oxy-hydroxides are deposited with volcanic ashes and angular fragments of pyroclastic simultaneously, and finally, they have made a cycle of manganese mineralization horizontally.

\section{References}

1. Kuleshow VN. Manganese deposits: communication 1. Genetic models of manganese ore formation. Lithol Mineral Resour. 2011; 46(5):473-93.

2. Roy S. Environment and processes of manganese deposition. Econ Geol. 1992; 87(5):1218-36.

3. Hein JR, Koschinsky A, Halbach P, Manheim FT, Bau M, Kang JK, Lubick N. Iron and manganese oxide mineralization in the Pacific. In: Nicholson K, Hein JR, Buhn B, Desgupta S, editors. Manganese Mineralization: Geochemistry and Mineralogy of Terrestrial and Marine Deposits. Geological Society Special Publication; 1997. p. 123-38.

4. Ingram BL, Hein JR, Farmer GL. Age determinations and growth rates of Pacific ferromanganese deposits using strontium isotopes. Geochim Cosmochim Acta. 1990; 54(6):1709-21. 
5. Roy S. Genetic diversity of manganese deposition in the terrestrial geological record. In: Nicholson K, Hein JR, Buhn B, Dasgupta S, editors. Manganese Mineralization: Geochemistry and Mineralogy of Terrestrial and Marine Deposits. London: Geological Society, Special Publication; 1997. p. 5-27.

6. Hein JR, Yeh HW, Gunn SH, Gibbs AE, Wang $\mathrm{CH}$. Composition and origin of hydrothermal ironstones from central Pacific sea mounts. Geochim Cosmochim Acta. 1994; 58(1):179-89.

7. Hein JR, Gibbs AE, Clague D, Torresan M. Hydrothermal mineralization along submarine rift zones, Hawaii. Mar Georesour Geotechnol. 1996; 14(2):177-203.

8. Shahabpour J. Economic Geology. Shahid Bahonar University of Kerman Publications; 2002. p. 543.

9. Arvin M, Robinson PT. The petrogenesis and tectonic setting of lavas from the Baftophiolitic Melange, southwest of Kerman, Iran. Canadian journal of Earth Sciences. 1994; 31:824-34.

10. Stocklin J, Eftekharnejad J, Hushmandzadeh A. Geology of the Shotori Range (Tabas area, East Iran). Geological Survey of Iran; 1965. p. 1-69.

11. Ruttner A, Nabavi M, Hajian J. Geology of the Shirgesht area (Tabas area, East Iran). Geological Survey of Iran; 1968. p. 1-33.

12. Nogole-Sadat MAA. Les zone de decrochementes et les virgation structurales en Iran. Consequences des resultants de 1 analysestructurale de la region de Qom. These Univ. Scientifiqueet Medicale de Grenoble; 1978. p. 201.

13. Berberian M, King G. Towards a pale geography and tectonic evolution of Iran. Canadian Journal of Earth Science. 1981; 18:210-65.

14. Alavi M. Tectonic map of the Middle East (1:2900000). Geological Survey of Iran; 1991.

15. Aghanabati SA. Geology of Iran. Tehran: Geological Survey of Iran; 2004. p. 586.

16. Ghorbani M. The Economic Geology of Iran. Mineral Deposits and Natural Resources. Springer Geology; 2013. p. 569.

17. Nabavi M. Introduction to Geology of Iran. Persian: Geological Survey of Iran press; 1976.

18. Eftekharnejad J. Tectonic division of Iran with respect to sedimentary basins. Journal of Iranian Petroleum Society. 1981; 82:19-28.

19. Tirrul R, Bell L, Griffis R, et al. The Sistan suture zone of eastern Iran. Geol Soc Amer Bull. 1983; 84:134-50.

20. Alavi M. Sedimentary and structural characteristics of the Paleo-Tethys remnants in northeastern Iran. Geological Society of America Bulletins. 1991; 103:983-92.

21. Shah MT, Khan A. Geochemistry and origin of Mn deposits in the Wazir is tanophiolite complex, north Waziristan, Pakistan. Miner Deposita. 1999; 34:697-704.
22. Polgari M, Hein JR, Vigh T, Szabo-Drubina M, Forizs I, Biro L, Muller A, Toth AL. Microbial processes and the origin of the Urkut manganese deposit, Hungary. Ore Geol Rev. 2012; 47:87-109.

23. Zarasvandi A, et al. Genesis of the Nasir a bad manganese occurrence, Fars province, Iran: Geochemical evidences. Chemie Erde Geochemistry; 2013.

24. Karakus A, Yavuz B, Koc S. Mineralogy and major-trace element geochemistry of the haymana manganese mineralizations, Ankara, Turkey. Geochem Int. 2010; 48:1014-27.

25. Nicholson K, Nayak VK, Nanda JK. Manganese ores of the Ghoriajhor Monmunda area, Sundergarh District, Orissa, India: geochemical evidence for a mixed $\mathrm{Mn}$ source. In: Nicholson K, Hein JR, Buhn B, Dasgupta S, editors. Manganese mineralization: Geochemistry and Mineralogy of Terrestrial and Marine Deposits. London: Geological Society, Special Publication; 1997. p. 117-21.

26. Crerar DA, Namson J, Chyi MS, Williams L, Feigenson MD. Manganiferous cherts of the Franciscan assemblage: I. General geology, ancient and modern analogues, and implications for the hydrothermal convection at oceanic spreading centers. Econ Geol. 1982; 77:519-40.

27. Sugisaki R. Relation between chemical composition and sedimentation rate of Pacific ocean floor sediments deposited since the middle Cretaceous: basic evidence for chemical constraints on depsitional environments of ancient sediments. J Geol. 1984; 92:235-59.

28. Sasmaz A, et al. Geology and geochemistry of Middle Eocene Maden complex ferromanganese deposits from the Elazig-Malatya region, eastern Turkey. Ore Geol Rev. 2013.

29. Choi JH, Hariya Y. Geochemistry and depositional environment of Mn oxide deposits in the Tokora Belt, norteastern Hokkaido, Japan. Econ Geol. 1992; 87:1265-74.

30. Toth JR. Deposition of submarine crusts rich in manganese and iron. Geol Soc Am Bull. 1980; 91:44-54.

31. Delian F. Geological and Geochemical Research of the Manganese ore Bed (in Chinese), M1. Beijing: Weather Publishing Press; 1994.

32. Fernandez A, Moro MC. Origin and depositional environment of Ordovician stratiform iron mineralization from Zamora (NW Iberian Peninsula). Miner Deposita. 1998; 33:606-19.

33. Oksuz N. Geochemical characteristics of the Eymir (SorgunYozgat) manganese deposits, Turkey. J Rare Earths. 2011; 29(3):287-96.

34. Monnin C, Wheat CG, Dupre B, Elderfield H, Mottl MJ. Barium geochemistry in sediment pore waters and formation waters of the oceanic crust on the eastern flank of the Juan de Fuca Ridge (ODP Leg 168). Geochem Geophys Geosyst. 2001; 2(1):1008.

35. Adachi M, Yamamoto K, Sugisaki R. Hydrothermal chert and assoicated siliceous rocks from the northern 
Pasific: their geological significance as indication of ocean ridge activity. Sediment Geol. 1986; 47:125-48.

36. Bonatti E, Kraemer T, Rydel H. Classification and genesis of submarine iron-manganese deposits. In: Horn DR, editors. Ferromanganese Deposits on the Ocean Floor, Washington, D.C. Natl Sci Found. 1972; 149-66.

37. Nicholson K. Stratiform manganese mineralization near Inverness, Scotland: a Devonian sublacustrine hot-spring deposit? Miner Deposita. 1990; 25:126-31.

38. Nicholson K. Contrasting mineralogical-geochemical signatures of manganese oxides: quides to metallogenesis. Econ Geol. 1992; 87:1253-64.

39. Peters T. Geochemistry of manganese-bearing cherts assoicated with Alpine ophiolites and the Hawasina formations in Oman. Mar Geol. 1988; 84(3-4):229-38.

40. Shah MT, Moon CJ. Manganese and ferromanganese ores from different tectonic settings in the $\mathrm{N}$ W Himalayas, Pakistan. J Asian Earth Sci. 2007; 29:455-65.

41. Hein JR, Schulz MS, Gein LM. Central Pacific cobalt rich ferromanganese crusts: historical perspective and regional variability. In: Keating BH, Bolton BR, editors. Geology and Offshore Mineral Resources of the Central Pacific Basin. Berlin: Springer-Verlag; 1992. p. 261.

42. Hein JR, Schulz MS, Kang JK. Insular and submarine ferromanganese mineralization of the Tonga-Lau region. Mar Min. 1990; 9(3):305-54.

43. Usui A, Someya M. Distribution and composition of marine hydrogenetic and hydrothermal manganese deposits in the Northwest Pasific. In: Nicholson K, Hein JR, Buhn B, Dasgupta S, editors. Manganese Mineralization: Geochemistry and Mineralogy of Terrestrial and Marine Deposits. Geol Soc Lond Spec Publ. 1997; p. 177-98.

44. Kato Y, Fujinaga K, Nakamura K, Takaya Y, Kitamura K, Ohta J, Toda R, Nakashima T, Iwamori H. Deep-sea mud in the Pasific Ocean as a potential resource for rare-earth elements. Nat Geosci. 2011; 4:535-9.

45. XuBao S, YangZhou H, TongPeng X, WuJi F, QiangYao H. Geochemistry of REE and yttrium in hydrothermal fluids from the Endeavour segment, Juande Fuca Ridge. Geochem J. 2008; 42:359-70.

46. Xie JC, Yang XY, Du JG, Xu W. Geochemical characteristics of sedimentary manganese deposit of Guichi, Anhui Province, China. J Rare Earths. 2006; 24(3):374-80.

47. Fitzgerald CE, Gillis KM. Hydrothermal manganese oxide deposits from Baby Bare seamount in the Northeast Pacific Ocean. Mar Geol. 2006; 225(1-4):145-56.

48. Nath BN, Pluger WL, Roelandts I. Geochemical constraints on the hydrothermal origin of ferromanganese encrustations from the Rodriguez Triple Junction, Indian Ocean. In: Nicholson K, Hein JR, Buhn B, Dasgupta S, editors. Manganese mineralization: Geochemistry and mineralogy of terrestrial and marine deposits. Geol Soc Spl Pub; 1997. p. 199-211.
49. Haskin LA, Frey FA, Schmitt R, Smith RH. Meteoritic, solar and terrestrial rare earth distributions. Phys Chem Earth. 1966; 7:167-321.

50. Bender ML, Broecker W, Gornitz V, Middel U, Kay R, Sun SS, Biscaye P. Geochemistry of three cores from the East Pasific Rise. Earth Planet Sci Lett. 1971; 12(4):425-33.

51. Dymond J, Corliss JB, Health GB, Field CW, Dash EJ, Weeh $\mathrm{HH}$. Origin of metalliferous sediments from the Pasific Ocean. Geol Soc Am Bull. 1973; 84(10):3355-72.

52. Graff JL. Rare earth elements in iron formations and sea water. Geochim Cosmochim Acta. 1978; 42(12):1845-50.

53. Kato Y, Yamaguchi KE, Ohmoto H. Rare earth elements in Precambrian banded iron formations: secular change of Ce and $\mathrm{Eu}$ anomalies and evolution of atmospheric oxygen. Geol Soc Amer Mem. 2006; 198:269-89.

54. Evensen MN, Hamilton P, O'Nions RK. Rare-earth abundances in chondritic meteorites. Geochim Cosmochim Acta. 1978; 42(8):1199-212.

55. Fleet HJ, Henderson P, Kepme DDC. Rare earth element and related chemistry of some drilled Southern Indian Ocean basalts and volcanogenic sediments. J Geophys Res (JGR). 1976; 81(23):4257-68.

56. De Carlo EH, McMurtry GM. Rare earth element geochemistry of ferromanganese crusts from the Hawaiilan Archi-pelago, central Pasific. Chem Geol. 1992; 95(3-4):235-50.

57. Hodkinson RA, Stoffers P, Scholten P, Cronan DS, Jeschke G, Rogers TDS. Geochemistry of hydrothermal manganese deposits from the Pitcairn Island hotspot, southeastern Pasific. Geochim Cosmochim Acta. 1994; 58(22):5011-29.

58. Kunzendorf H, Glasby GP. Minor and rare earth elements in manganese crusts and nodules and sediments from the Manihiki Plateau and adjacent areas: results of HMNZS Tui Cruises. Mar Georesour Geotechnol. 1994; 12(4):271-81.

59. Michard A. Rare earth element systematics in hydrothermal fluids. Geochim Cosmochim Acta. 1989; 53(3):745-50.

60. Usui A, Mita N. Geochemistry and mineralogy of a modern buserite deposit from a hot spring in Hokkaido, Japan. Clays Clay Miner. 1995; 43(1):116-27.

61. Sun SS, McDonough WF. Chemical and isotopic systematics of oceanic basalts: implications for mantle compositions and processes. In: Saunders AD, Norry MJ, editors. Magmatism in the Ocean Basins. Geological Society, Special Publication; 1989. p. 313-45.

62. Wonder JD, Spry PG, Windom KE. Geochemistry and origin of manganese rich rocks related to iron formation and sulfide deposits, western Georgia. Economic Geology. 1988; 83(5):1070-81.

63. Stackelberg V. Growth history of manganese nodules and crusts of the Peru Basin. London: Geological Society, Special Publications; 1997. p. 153-76. 